\title{
Family Planning Knowledge, Attitude and Practice among Married Couples in Abakpa Nike, Enugu East Local Government Area, Enugu State, Nigeria
}

\author{
Article by Mgbe Chinenye $\mathrm{G}^{1}$, Mgbe Emeka Kevin ${ }^{2}$, Rita Uzoamaka Nwali ${ }^{3}$, Odenigbo \\ Josephine C \\ ${ }^{1}$ Ph.D, Enugu State University Teaching Hospital \\ ${ }^{2} \mathrm{MBBS}$, fWACS, University of Nigeria Teaching Hospital Ituku \\ E-mail: chinenyemgbe@yahoo.com ${ }^{1}$, champlinks2001@yahoo.com ${ }^{2}$, \\ makasonchrist@yahoo.com ${ }^{3}$
}

\begin{abstract}
This study set out to assess family planning knowledge, attitude and practice among married couples in Abakpa Nike, Enugu East Local Government Area, Enugu State. A survey design approach was adopted for the study. Out of a population of 1130 married couples, 295 of them were randomly selected through taro yamane. Four research questions were formulated and analyzed in the course of this study. The mean value statistical analysis was used to analyze the research questions of the study. The results showed that there is positive knowledge of family planning methods among married couples in Abakpa. Husband's involvement in family decision, support of national policy of 4 children per family and Contraceptives actually being effective in planning families; control the attitude of married couple towards the use family planning methods in Abakpa Nike, Enugu. There is adequate practice of family planning methods among married couples in Abakpa. Effectiveness and Partner involvement were the major factors influencing the Choice of Family Planning in Abakpa Nike, Enugu. Consequent upon the findings, the following recommendations, among others, were made: It is therefore necessary for religious leaders to be targeted and carried along in the campaign for modern contraceptive methods. The mass media should also be encouraged to do more in public (eg traditional method) have been associated with high enlightenment on the benefits of modern contraceptive methods. So, awareness and pattern of utilizing family planning services among married couples in Abakpa Nike, Enugu should be encouraged.
\end{abstract}

Keywords: Family planning, Contraceptives, married couples, Mortality.

\section{Introduction}

\section{Background of the study}

The alarming rate at which the population of the world is increasing demands adequate and immediate attention ${ }^{14}$. This is needed to curb problem of social, ecological, economic and general welfare problems of all individuals. As a matter of fact, the survival of the human race is endangered if population growth is not checked adequately.

In a developing country like Nigeria, over population is a major concern and the main reason is that our resources are no longer enough to cater for the citizens, hence the increased poverty. Despite the progress recorded from making contraception widely available, there is poor acceptance of contraceptive methods either due to ignorance or fear of complications or side effects using them ${ }^{13}$. Inadequate knowledge about contraception and its methods, incomplete or erroneous information about their use or where they procure them and the attitudes of the health care providers at the clinics are the main reasons for not accepting family planning ${ }^{22}$. There is a trade-off between safety and efficiency of contraceptives in practice. The decisions about family planning are made by people themselves based on accurate and choosing from a range of contraceptive options. Family planning can be used by people who make informed choice. Providers and their programs have the responsibility to help people make informed family planning choices. Approximately $60 \%$ of all pregnancies are unplanned and knowledge about the various methods of contraception preventing 
unwanted pregnancy is directly related to education and knowledge about the various methods of contraception ${ }^{12}$.

According to Rozina ${ }^{20}$ family planning is now recognized as a basic human right and it must be seen as part of preventive health. Despite all endeavours to reduce the number of birth through family planning in Nigeria, there are a lot of problems still emanating. Considering the population of Nigeria which was estimated at 100 million in the year 2000 and with a growth rate of over three percent; it was projected that there might be 150 million heads swinging around in the country by the year 2010 . This has come to pass. Also, Nigerian's report on the implementation of the Beijing platform for action and common wealth plan of action by the Federal Ministry of Women Affairs (2004) cited in Olakojo $^{12}$, estimates that Nigeria's population was about 120 million and an annual growth rate of $2.8 \%$ spread over 350 ethnic groups and two major religions, Islam and Christianity. It is, however, projected that there may be as many as 174 million heads in the country by the year 2020 and the repercussion of such a growth rate in the nation's economic development and social services call for great concern (Federal Ministry of Women Affairs, 2004). Dixon-mullen cited in Olakojo, ${ }^{12}$ states that African from time of their ancestors is known to bear many children. It was believed that having many children was a pride and a way of boosting one's ego. Providing enough labour and increasing the productivity on the farms. Fajobi cited in Olakojo, ${ }^{12}$ discovers that another major problem hindering modern family planning in Nigeria is illiteracy, he describes illiterates as the worst offenders of unplanned families. Majority of the married people in the rural areas of the six geo political zones are illiterates and they are ignorant of the importance and necessity of the modern family planning programme and alternatively, they rather prefer to ask their children to stay or live with other family members who are financially capable than themselves.

US Department of Agriculture Centre for Nutrition Policy and Promotion ${ }^{24}$ have pointed out various ways of controlling birth before the modern family planning came into existence and natural traditional method of family planning have been in use before the introduction of contraceptives. Family planning is a vital issue to investigate considering the rapid increase of Nigeria's population. The population of Nigeria today increases tremendously thus, posing problem of survival to the members of individual families. Africans have now advanced to the stage of developing modern family planning devices which are more effectives than the method that were adopted in the early years or century. The types of family planning methods used in the old days include: abstinence, polygamy, celibacy, menstruation, douching, oral method, scarification, charms, spiritual power, local herbs in the vagina to stimulate contraction and dilation of the cervix. In the modern times, contraceptives used are: condoms, intrauterine devices (U.I.D) oral, sterilization, injectables, implant; sterilization, Diaphragm and safe period are also used in Nigeria ${ }^{7}$.

\section{Statement of the problem}

The relevance of family planning cannot be over emphasized since is now recognized as a basic human right and seen as part of preventive health measures ${ }^{19}$. Fortunately, majority of Nigerian married couples are aware of family planning, but very few of them make use of it for birth control. Different factors such as culture, low education, poverty and poor access among other numerous factors have been identified by scholars to militate against the use of family planning methods ${ }^{24}$. For example, ${ }^{17}$ alleged that traditionally, most Nigerian cultures are highly patriarchal, value high fertility and male child preference. This perhaps could have a negative impact on the utilisation of family planning services. A study carried out by Isiugo-abanihe cited in Lasisi, Bassey, Ita, \& Awoyemi ${ }^{9}$ on reproductive motivation and family size preferences among Nigerian men revealed that the characteristic male dominant and patrilineal traditions support large family sizes and that men's reproductive motivation to a large extent, affect the reproductive behaviour of their wives. These cultural values undermine the utilisation of family planning in many communities in Nigeria like the traditional core areas of Enugu especially Abakpa Nike, where families still support large family sizes of more than four children per woman, and where polygamy is commonly practiced.

More so, in most cases especially in rural areas, women do not have a say when it comes to family planning issues and reproductive health care independency and survival Olutayo, cited in Lasisi, Bassey, Ita, \& Awoyemi, ${ }^{9}$. Also, Ozumba ${ }^{19}$ maintained that many rural women have been threatened, 
abused, beaten and sometimes overpowered when it comes to sexual play and matter that concerns family planning. A lot of research has been done on this subject in the past but heavily skewed to married women's self-identified barriers on the use of family planning measures but sparse literature exist in Nigeria on the area of knowledge, attitude and practice of family planning among married couples.

\section{Objectives of the study}

The objective of this study is to assess family planning knowledge, attitude and practice among married couples in Abakpa Nike, Enugu East Local Government Area, Enugu State

\section{Scope and delimitation of the study}

This project work is structured to cover family planning knowledge, attitude and practice among married couples with Abakpa Nike as study reference. Abakpa is composed of five district areas which include Ugboghe, Ogwuago, Ugbene I, Ugbene II, and Ugboezeji.Abakpa Nike was chosen due to proximity reason and easy accessibility of data and that it would serve as good sample to assess family planning knowledge, attitude and practice among married couples. Drawbacks were actually observed which contradict the initial plan, which aimed at covering all areas in Enugu State, but due to financial incapacitation, time and uneasy accessibility of data, the researcher however delimited the scope, selecting only Abakpa Nike in Enugu East.

\section{Definition of operational terms}

Family planning: Family planning involves a conscious effort by couple to limit or space the number of children they want to have through the use of contraceptive methods. It also refers to the steps, practices and techniques adopted to determine, influence or decide when to have children ${ }^{11}$.

Contraception: Contraception as a concept can also be defined as means of controlling fertility by using various methods that prevent conception ${ }^{18}$.

Marriage: Marriage, also called matrimony or wedlock, is a socially or ritually recognized union or legal contract between spouses that establishes rights and obligations between them, between them and their children, and between them and their in-laws

Couple: two people who are married or otherwise closely associated romantically or sexually

Married Couple: two people who are married to each other.

Mortality: The incidence of death in the population in a given period.

\section{Literature review}

The review commenced with the conceptual framework of the study which encompassed the concept of family planning, Factors Influencing the Choice of Family Planning, Contraception, Types of Contraceptives and their Function. This was followed with the theoretical framework where theory that has direct bearing to this study was reviewed and finally, empirical evidence from different scholars was covered under this chapter.

\section{Conceptual framework}

\section{Concepts of family planning}

Family planning is the planning of when to have and use birth techniques to implement such plans ${ }^{13}$. Other techniques commonly used include sexual education, prevention and management of sexually transmitted diseases, pre-conception counselling, management and infertility management ${ }^{2}$. The concept of informed choice in family planning can be applied to a wide range of sexual and reproductive health decisions. It focuses on whether to seek, to avoid pregnancy, whether to space and time one's 'childbearing, whether to use contraception, what family methods to be used, and whether or when to continue or switch methods. The term family planning choice could also refer to the family decision making ${ }^{3}$. The principles of informed choice focus on the individual; however, it also influences a range of outside factors such as: social, economic and cultural norms, gender roles, social networks, religious and local beliefs, ${ }^{4}$. To a large extent, these community norms determine individual childbearing preferences and sexual and reproductive behaviour. It is usually thought that community 
and culture affect a person's attitudes towards family planning, desire for sex of children, preferences about family size, family pressures to have children and whether or not family planning accords with customs and religious beliefs ${ }^{4}$. Community norms also reflect how much autonomy individuals have in making family planning decisions. The larger the differences in reproductive intentions within a community, the more likely that community norms support individual choices ${ }^{5}$. Household and community influences can be so powerful that they can obscure the line between individual desires and community norms. For instance, in some culture, many women reject contraception because bearing and raising children is the path to respect and dignity in the society ${ }^{13}$. In either country, most women use contraception because having small families is the norm ${ }^{13}$. People are often unaware that such norms influence their choices. In other cases, they are particularly aware. For example, young people often decide not to seek family planning because they do not want their parents or other adults to know that they are sexually active, while many fear ridicule, disapproval and hostile attitude from service providers and others. A person's social environment usually has more influence on family planning decisions that influence the attributes of specific contraceptives.

\section{Factors influencing the choice of family planning}

A myriad of different factors affect a person's personal decisions about what types of family planning method he should use:

\section{a. Effectiveness}

People who are not in a financial or emotional situation to have children might opt for the most effective type of family planning in order to avoid pregnancy. A couple or woman with a casual approach towards parenthood, such as not actively pursuing it, but not unwilling to take it on, might choose a less certain form of contraception, such as natural family planning.

\section{b. Religion}

Some religions, such as Catholicism, have restrictions on contraception based on the belief that it is God's will to bring children into the world. According to Dixon-Muller cited in Olaitan ${ }^{13}$, religious believers or observers might choose to avoid certain methods of family planning, such as birth control pill, in an effort to live their lives according to the teachings of their religion.

\section{c. Cost}

Some forms of contraception, such as minor surgery (like vasectomy), carry a fairly significant amount of one's time and is very cost as compared to other options, such as condom or the calendar cycle methods which are less expensive; hence, couples engage in them.

\section{d. Health risk}

For people with multiple sexual partners, the choice to use family planning devices helps them to keep healthy. For example, using condoms can reduce the chance of contracting sexually transmitted diseases.

\section{e. Permanence}

Some contraception choices, such as vasectomy, are usually permanent. So couples who do not want to have children at present, but would like to have one in the future, might want to choose a less - permanent option such as condoms or birth control pills.

\section{f. Partner involvement}

One has to consider the preferences of his or her partner when choosing a birth control option. For example, some men do not like to have sex using a condom. In that case, birth control pills might be a better choice for preventing an unwanted pregnancy, according to the National Institute of Health ${ }^{16}$.

\section{g. Socio-economic factors}

There are some contraceptive methods of family planning that are expensive, and some couples cannot afford to use or purchase them due to their financial situations in the society. For instance, 
people in rural areas cannot afford to use the expensive contraceptive methods of family planning such as vasectomy, Intra-uterine devices (IUD) (which are small, flexible, plastic frame inserted in the vagina of women) and female sterilization method.

\section{h. Cultural norms factors}

This is the most important factor influencing the choice of family planning among couples. This includes: community norms, religious belief and gender role.

\section{i) Community norms}

Community norms also prescribe how much autonomy an individual has in making family planning decisions. The larger the differences in reproductive intentions within a community, the more likely the community norms support individual choices. Household and community influence can be so powerful that they can obscure the line between individual desires and community norms

\section{Religious factors}

Family planning choice depends on the religion of the couple. It may be Islam or Christianity that calls for raising and bearing of more children in the society. Some religions, such as Catholicism, have restriction on contraception based on the belief that it is "God's will to bring children" into the world.

\section{ii) Gender role}

Some couples want to have a male child; and in cases when the child born to them is female, the family is unhappy. Therefore, the couple may wish to have another child in order to have a male child $^{6}$.

\section{Male involvement in family planning}

In recent times, many in the reproductive health field have come to appreciate the need for the constructive involvement of men in programs and services. The 1994 International Conference on Population Development (ICPD) held in Cairo articulated why and how male involvement should occur. Recognition is growing that men are interested in and need reproductive health information and services, both for their partners and for themselves ${ }^{6}$ and that the reproductive health of individuals depends heavily on the relationship between two people concerned. Awareness has increased that services should be directed not only towards women but also towards men and couples ${ }^{6}$. Before the current concern for male involvement began, reproductive health issues and services had become synonymous with women's reproductive health, and men were assumed to have no special interest in such matters. Indeed, the characteristic lack of male involvement in reproductive initiatives, including family planning, is a major obstacle to a speedy fertility decline in sub-Saharan Africa given the considerable authority and power vested on men as decision makers in the home and society ${ }^{6}$.

\section{Contraception}

Contraception as a concept can also be defined as means of controlling fertility by using various methods that prevent conception. These methods can be traditional or modern. Traditional methods include: withdrawal method, abstinence, douche method and vaginal sponge ${ }^{1}$. Withdrawal method, also referred to as coitus interruptus ${ }^{18}$, is probably the oldest technique which couples adopted in order to avoid having children. It refers to the withdrawal of the penis from the woman's vagina just prior to ejaculation so that the semen is deposited outside of the genital tract. Another oldest method is the Douche. It consists of flushing out the vagina with water after sexual intercourse in an effort to prevent pregnancy by removing semen. In 1958, the first oral contraceptive pill was tested and subsequently introduced in May 1960. Before then however, a German physician, Ernest Graefenberg, had developed the intrauterine device (IUD) in $1929^{21}$; but the knowledge of the existence of IUD was limited to a few countries in Europe and America. Other modern medical advances in family planning include surrogacy and sperm donor. In surrogacy, a woman agrees to become pregnant and deliver a child for another couple or person. There are two types of surrogacy: Traditional Surrogacy and Gestational Surrogacy. In traditional surrogacy, a woman uses her own 
eggs and carries the child for her intended parents. This type involves a genetic connection between the surrogate and the child. On the other hand, a gestational surrogacy occurs when the intended mother's or a donor egg is fertilized outside the body and then the embryos are transferred into the uterus. The woman who carries the child is often referred to as a gestational carrier ${ }^{23}$. The method is not popular in Africa, but records show that is a common practice in some parts of India, and now a preferred destination to many North American women who patronize the system ${ }^{18}$. In sperm donor, pregnancies are usually achieved by using donated sperm through artificial insemination (either by intracervical insemination or intrauterine insemination) and less commonly by Invitro fertilization (IVF), usually known in this context as Assisted Reproductive Technology (ART). Insemination may also be achieved by a donor having sexual intercourse with a woman for the sole purpose of initiating conception. This method is known as natural insemination ${ }^{23}$. Olawepo ${ }^{15}$ notes that there is a generally a demand for sperm donors who have no genetic problems in their family, 20/20 eyesight, with excellent visual acuity and sometimes, a value on a certain height and age.

\section{Research design and methodology}

\section{Study area}

This study is pegged on Abakpa Nike, Enugu East local government area of Enugu State. Abakpa Nike is from Enugu East and is comprising of five district areas, namely: Ugboghe, Federal Housing, Ogwuago, Ugboezeji Ugbene I and Ugbene II. Enugu east is one of the seventeen (17) local governments in Enugu state. Its headquarter is in the town of Nkwo Nike. It has an area of $383 \mathrm{~km}^{2}$ and a population of 279,089 at the 2006 census. The postal code of the area is 400 .

\section{Source of data}

Data used for the study were collected from both Primary and Secondary sources.

\section{Primary source of data}

A primary source is an original object or document- the raw material or first-hand information.

\section{Secondary source of data}

This can be defined as any published or unpublished work that is one step removed from the original source, usually describing, summarizing, analyzing, evaluating, derived from, or based on primary source materials

\section{Determination of sample size}

To ensure effective study, the researcher used a statistical formula (Yaro Yamane's formula) for a finite population size of 1130 married couples (N) to obtain 295 as the sample size (n) which represents also the number of the questionnaires administered accordingly.

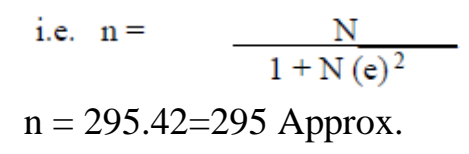

Using Bowley's formula, the sample size of 295 will be allocated to different strata

$$
\mathrm{ni}=\frac{\mathrm{Nixn}}{\mathrm{N}}
$$

Where ni $=$ strata sample

$\mathrm{Ni}=$ Population size of the strata

$\mathrm{N}=$ Population size of the strata

Ogwuago $=\frac{220 \times 295}{1130}=58$
Federal Housing $=\frac{100 \times 295}{1130}=26$
Ugboghe $-=\frac{250 \times 295}{1130}=65$ 
Ugboezeji $\quad \frac{230 \times 295}{1130}=60$
Ugbene I $\quad \frac{200 \times 295}{1130}=52$
Ugbene II $=\frac{130 \times 295}{1130}=\underline{34} 295$

However, the researcher distributed 295 copies of questionnaire, in an attempt to ensure greater validity of the study and was able to collect back 290. This gave a response rate of about $98 \%$. This was considered high enough for this study. However, three (3) copies of the questionnaire were not returned while two (2) copies were rejected because it was not properly completed.

\section{Research instrument}

The main instrument used in data collection was Questionnaire. The survey questionnaire was organized on a - 5 Likert scale response options Strongly Agree (SA), Agree (A), Undecided (U), Strongly Disagree (SD), and Disagree (D) and also on "Yes" or "No" as well as "Suggestive options" questions. Also, the researcher also used "Content Validity" which emphasized mainly on the adequate coverage by the instrument of the scope implies by the topic of study.

It was revealed that the entire questions asked in the questionnaire fully exhausted all implied by the research questions.

\section{Administration and collection of the questionnaire}

The face to face method of distribution of questionnaire was adopted .The researcher administered 295 copies of questionnaire, in an attempt to ensure greater validity of the study and was able to collect back 290 copies. This gave a response rate of about $98 \%$. This was considered high enough for this study. However, 2 copies of questionnaire were rejected because they were not properly completed while 3 are non-returnable. In sum, 290 copies of questionnaire were collected which gave a response rate of about $98 \%$ and same were used for analysis.

\section{Method of data analysis}

The data collected were analyzed through the use of tables and simple percentages and mean value. Mean value will be determined as follows:

$$
\frac{5+4+3+2+1}{5}=3.00
$$

The implication is that any items with mean value of 3.00 is accepted as "agree" while any item with mean value less than 3.00 is "disagree".

\section{Ethical issue}

Ethical clearance was obtained from the Esut Teaching Hospital Parklane Enugu Ethical Committee. Informed consent will be obtained from all participants.

\section{Results, analysis and findings}

The copies of questionnaire were administered to the married couples in Abakpa Nike, Enugu. A total of 295 copies of questionnaire were issued to the. Out of the 295 questionnaire issued, 290 were dully filled and returned to the researcher by the respondents. Three (3) copies of questionnaire were however not returned and Two (2) copies of questionnaire were not properly filled which both represents $2 \%$ of the issued questionnaires. Therefore, the $98 \%$ of the copies of the questionnaire which were duly filled returned and were used for the presentation and analysis for this research study. 
DOI: $10.21522 /$ TIJPH.2013.06.02.Art022

ISSN: $2520-3134$

\section{Analysis and results}

Table 1. Socio-demographic characteristics of respondents $(\mathrm{n}=290)$

\begin{tabular}{|c|c|c|}
\hline $\begin{array}{l}\text { Variables/Options } \\
\text { Age Group } \\
\text { (Years) } \\
\end{array}$ & $\begin{array}{l}\text { No. of } \\
\text { Respondent }\end{array}$ & Percentage (\%) \\
\hline 19 and less & 35 & 12 \\
\hline $20-24$ & 43 & 15 \\
\hline $25-29$ & 73 & 25 \\
\hline $30-34$ & 54 & 19 \\
\hline 35 and above & 85 & 29 \\
\hline \multicolumn{3}{|l|}{ Religion } \\
\hline Christianity & 280 & 97 \\
\hline Islam & 9 & 3 \\
\hline Traditional & 1 & - \\
\hline \multicolumn{3}{|c|}{ Educational Status } \\
\hline $\begin{array}{l}\text { No formal } \\
\text { education }\end{array}$ & 33 & 11 \\
\hline Primary School & 71 & 24 \\
\hline Secondary School & 147 & 51 \\
\hline Tertiary & 39 & 14 \\
\hline \multicolumn{3}{|l|}{ Family Setting } \\
\hline Monogamy & 235 & 81 \\
\hline Polygamy & 55 & 19 \\
\hline \multicolumn{3}{|l|}{$\begin{array}{l}\text { Children ever } \\
\text { born: }\end{array}$} \\
\hline $0-2$ & 94 & 32 \\
\hline $3-4$ & 93 & 32 \\
\hline $5-6$ & 58 & 20 \\
\hline Above 7 & 45 & 16 \\
\hline \multicolumn{3}{|c|}{ Additional child wanted } \\
\hline Yes & 210 & 72 \\
\hline No & 80 & 80 \\
\hline \multicolumn{3}{|l|}{ Occupation } \\
\hline Farming & 1 & - \\
\hline Trading & 5 & 2 \\
\hline Civil Servant & 36 & 15 \\
\hline Housewife & 6 & 2 \\
\hline Student & 39 & 16 \\
\hline Unemployed & 33 & 14 \\
\hline Others & 123 & 51 \\
\hline
\end{tabular}

Source: Field survey, 2016.

More of the respondents were in the age range of 35 years and above, 85(29\%) followed by 25 to 29 years 73(25\%), with a mean age of $29.59 \pm 8.57$ years. Most of them were Christian 280(97\%), and had secondary school education $147(51 \%)$, majority of the married couples were monogamy 235(81\%) with Children ever born not mostly exceed 4 children, the response rate shown $0-2(32 \%)$ and 3-4 93(32\%), upon this, majority of respondents, 210(72\%) gave consent for additional child while other occupation unspecified was the major vocation, $123(51 \%)$ among the respondents (Table 1). 
Table 2. Knowledge of respondents about contraception $(\mathrm{n}=290)$

\begin{tabular}{|l|l|l|}
\hline Variables/Options & $\begin{array}{l}\text { No. of } \\
\text { Respondent }\end{array}$ & Percentage (\%) \\
\hline Meaning of Contraception & 51 \\
\hline $\begin{array}{l}\text { Prevention of } \\
\text { unwanted } \\
\text { pregnancy }\end{array}$ & 149 & 16 \\
\hline Child spacing & 46 & 28 \\
\hline Limit family size & 80 & 5 \\
\hline Prevent sexually & 15 & \\
\hline Sources of Information & 20 \\
\hline Friends / Relatives & 59 & 53 \\
\hline Health personnel & 153 & 4 \\
\hline $\begin{array}{l}\text { Printed medial } \\
\text { (postal, hand bill) }\end{array}$ & 12 & 23 \\
\hline $\begin{array}{l}\text { Electric media } \\
\text { (Radio, TV) }\end{array}$ & 66 & \\
\hline Knowledge of Side - effects & 90 \\
\hline None & 260 & 1 \\
\hline Weight gain & 3 & 1 \\
\hline Weight loss & 2 & 5 \\
\hline Condom burst & 15 & 1 \\
\hline $\begin{array}{l}\text { Extra marital } \\
\text { affairs }\end{array}$ & 3 & 1 \\
\hline Amenorrhea & 2 & 1 \\
\hline $\begin{array}{l}\text { Secondary } \\
\text { infertility }\end{array}$ & 3 & - \\
\hline Heavy menses & 1 & - \\
\hline Dislodgement & - & 21 \\
\hline Irregular menses & 1 & \\
\hline Decider of Family Planning Method & \\
\hline Husband & 109 & \\
\hline Wife & 62 & \\
\hline Both & 119 & \\
\hline & & \\
\hline & & \\
\hline
\end{tabular}

Source: Field survey, 2016.

In Table.2, some of the respondents understood contraception to mean prevention of unwanted pregnancy $149(51 \%)$ and limiting the family size $80(28 \%)$, their source of information was mainly the health personnel, 322(52.6\%). Majority of the women, 260 (90\%) did not know any side-effect of contraceptives and $15(5 \%)$ of them reported condom burst/spillage as a side-effect of condom use. One hundred and nine, 109 (38\%) respondents felt the husband should solely decide on family planning, while $62(21 \%)$ felt it was the wife, but $119(41 \%)$ felt it is a joint responsibility of husband and wife/partner. 
DOI: $10.21522 /$ TIJPH.2013.06.02.Art022

ISSN: $2520-3134$

Table.3. Knowledge about contraceptive methods $(n=290)$

\begin{tabular}{|l|l|l|}
\hline Variables/Options & $\begin{array}{l}\text { No. of } \\
\text { Respondent }\end{array}$ & $\begin{array}{l}\text { Percentage } \\
(\%)\end{array}$ \\
\hline Traditional & & \\
\hline Armlet & 89 & 31 \\
\hline Ring & 180 & 62 \\
\hline Pad lock & 112 & 39 \\
\hline Waist band & 109 & 38 \\
\hline Natural & & \\
\hline Periodic Abstinence & 264 & 91 \\
\hline Rhythm & 172 & 59 \\
\hline $\begin{array}{l}\text { Lactational } \\
\text { amenorrhoea }\end{array}$ & 144 & 50 \\
\hline Coitus interruptus & 168 & 58 \\
\hline Barrier & & \\
\hline Male condom & 286 & 99 \\
\hline Female condom & 3 & 1 \\
\hline Diaphragm & 90 & 31 \\
\hline IUCD & 183 & 63 \\
\hline Hormonal & & \\
\hline Injectable & 246 & 85 \\
\hline Implants & 92 & 32 \\
\hline Pills & 243 & 84 \\
\hline Surgical & & 1 \\
\hline Vasectomy & 2 & - \\
\hline $\begin{array}{l}\text { Bilateral tubal } \\
\text { ligation }\end{array}$ & - & \\
\hline
\end{tabular}

Source: Field survey, 2016

From table.3 above, Rings 180(62\%), abstinence 264(91\%), male condom 286(99\%) and injectable $246(85 \%)$ were the most well-known traditional, natural, barrier and hormonal methods respectively.

Table.4. Distribution of respondents, on whether there is positive knowledge of family planning methods among married couples in Abakpa

\begin{tabular}{|l|l|l|}
\hline Response & Frequency & $\begin{array}{l}\text { Percentages } \\
(\%)\end{array}$ \\
\hline Strongly Agree & 180 & 62 \\
\hline Agree & 90 & 31 \\
\hline Undecided & 15 & 5 \\
\hline Strongly Disagree & 3 & 1 \\
\hline Disagree & 2 & 1 \\
\hline Total & 290 & 100 \\
\hline
\end{tabular}

Source: Field survey 2016

From the table 4.1 .4 above, $62 \%$ of the respondents strongly agree that there is positive knowledge of family planning methods among married couples in Abakpa supported by $31 \%$ of the respondents representing respondents that agree on the fact. As could be seen on the table, only $1 \%$ of the respondents strongly disagree while $1 \%$ gave them support as they just disagree with the fact. These two groups do not think that there is positive knowledge of family planning methods among married couples in Abakpa. The remaining 5\% with undecided representing 15 out of 290 respondents do not belong to either side. Based on these observations, it can be deduced that there is positive knowledge of family planning methods among married couples in Abakpa. 


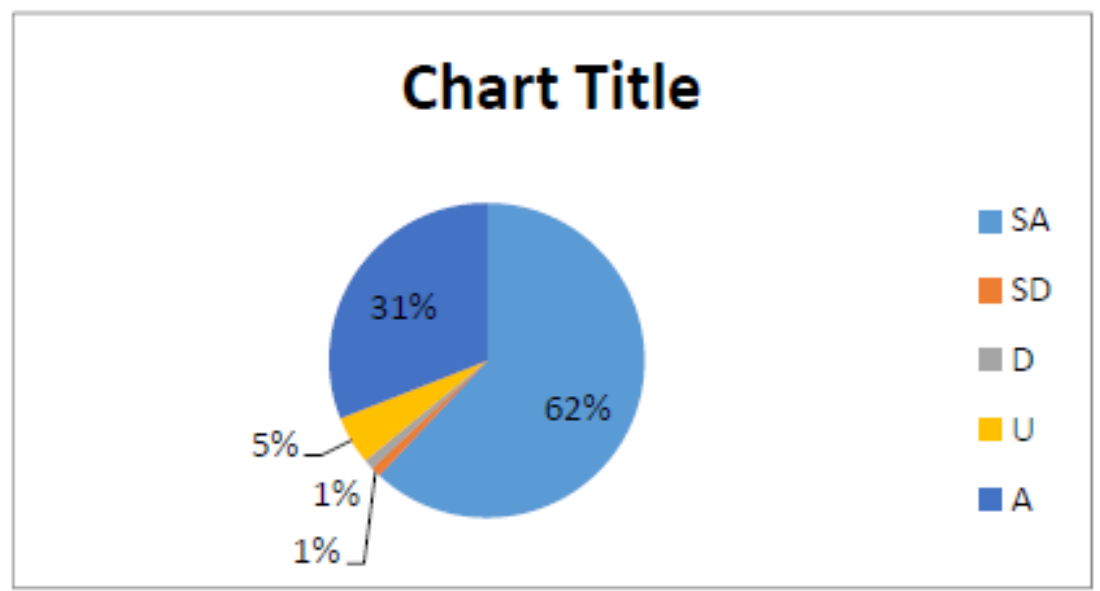

Figure 1. Pie chart showing the distribution of respondents, on whether there is positive knowledge of family planning methods among married couples in Abakpa

From the pie chart above, strongly agree received the biggest chunk of the respondents representing $62 \%$ that there is positive knowledge of family planning methods among married couples in Abakpa followed by $31 \%$ of the respondents representing respondents that agree on the fact. As could be seen on the pie chart, only $1 \%$ of the respondents strongly disagree while $1 \%$ gave them support as they just disagree with the fact. These two groups do not think that there is positive knowledge of family planning methods among married couples in Abakpa. The remaining 5\% with undecided representing 15 out of 290 respondents do not belong to either side.

Table 5. Practices of contraceptives/family planning $(\mathrm{n}=290)$

\begin{tabular}{|l|l|l|}
\hline Variables & frequency & $\begin{array}{l}\text { Percentage } \\
(\%)\end{array}$ \\
\hline \multicolumn{2}{|l|}{ If currently using a method of family planning } \\
\hline Yes & 250 & 86 \\
\hline No & 40 & 14 \\
\hline If approve the use of modern methods of family planning \\
\hline Yes & 240 & 83 \\
\hline No & 50 & 17 \\
\hline $\begin{array}{l}\text { Intend to use a modern method of family planning to } \\
\text { prevent pregnancy in the future }\end{array}$ \\
\hline Yes & 200 & 69 \\
\hline No & 90 & 31 \\
\hline Method(s) ever used & 243 & 84 \\
\hline Pills & 246 & 85 \\
\hline Injection & 286 & 99 \\
\hline Male condom & 5 & 2 \\
\hline Norplant & 183 & 63 \\
\hline IUD & 5 & 2 \\
\hline Female sterilization & 75 & 26 \\
\hline Why using contraceptives & 49 \\
\hline No reason & 75 \\
\hline $\begin{array}{l}\text { Affordable and } \\
\text { available }\end{array}$ & 142 & 21 \\
\hline $\begin{array}{l}\text { Little or no side } \\
\text { effect }\end{array}$ & 58 & \\
\hline $\begin{array}{l}\text { Suitable effective / } \\
\text { reliable }\end{array}$ & 62 & \\
\hline
\end{tabular}


DOI: $10.21522 /$ TIJPH.2013.06.02.Art022

ISSN: $2520-3134$

\begin{tabular}{|l|l|l|}
\hline Why not using contraceptives & 2 \\
\hline $\begin{array}{l}\text { It is sin in my } \\
\text { religion }\end{array}$ & 7 & 16 \\
\hline No reason & 45 & 4 \\
\hline Side effect & 13 & 2 \\
\hline $\begin{array}{l}\text { Husband's } \\
\text { disapproval }\end{array}$ & 6 & 1 \\
\hline $\begin{array}{l}\text { Desire for more } \\
\text { children }\end{array}$ & 4 & \\
\hline
\end{tabular}

Source: Field survey 2016

In table 5, majority of the respondents $250(86 \%)$ were currently using a modern contraceptive method. A good proportion of the respondents indicated their continued practice of modern contraceptive method even in the future as evident by 200(69\%) accepting to use a modern method of family planning to prevent pregnancy in the future. The respondents mostly practice Male condom, Injection, Pills and IUD with 286(99\%), 246(85\%), 243(84\%) and 183(63\%) as their response rates respectively. The main reason given for choice of contraceptive methods was affordability and availability, 142 (49\%), followed by reliability by $21 \%$ of the respondents. Most of the non-users $45(16 \%)$ did not have any reason for not using any method.

A close look on the bar chart above indicates that majority of the respondents $250(86 \%)$ were currently using a modern contraceptive method. A good proportion of the respondents indicated their continued practice of modern contraceptive method even in the future as evident by 200(69\%) accepting to use a modern method of family planning to prevent pregnancy in the future. The respondents mostly practice Male condom, Injection, Pills and IUD with 286(99\%), 246(85\%), $243(84 \%)$ and $183(63 \%)$ as their response rates respectively. The main reason given for choice of contraceptive methods was affordability and availability, 142 (49\%), followed by reliability by $21 \%$ of the respondents. Most of the non-users 45(16\%) did not have any reason for not using any method.

Table 6. Distribution of respondents, on whether there is adequate practice of family planning methods among married couples in Abakpa

\begin{tabular}{|l|l|l|}
\hline Response & Frequency & $\begin{array}{l}\text { Percentage } \\
\text { ( }(\%)\end{array}$ \\
\hline Strongly Agree & 120 & 41 \\
\hline Agree & 140 & 48 \\
\hline Undecided & 15 & 5 \\
\hline Strongly Disagree & 3 & 1 \\
\hline Disagree & 2 & 1 \\
\hline Total & 290 & 100 \\
\hline
\end{tabular}

Source: Field survey 2016

From the table 6 above, $41 \%$ of the respondents strongly agree that there is adequate practice of family planning methods among married couples in Abakpa supported by $48 \%$ of the respondents representing respondents that agree on the fact. As could be seen on the table, only $1 \%$ of the respondents strongly disagree while $1 \%$ gave them support as they just disagree with the fact. These two groups do not think that there is adequate practice of family planning methods among married couples in Abakpa. The remaining 5\% with undecided representing 15 out of 290 respondents do not belong to either side. Based on these observations, it can be deduced that there is adequate practice of family planning methods among married couples in Abakpa.

\section{Analysis and results of the research questions}

This involves collation and analysis of data according to the research questions. To arrive at a conclusion, the average of the five likert point scale would be taken thus: 


$$
\overline{\mathrm{X}}=\frac{\sum \mathrm{FX}}{\sum \mathrm{F}}=\frac{5+4+3+2+1}{5}=\frac{15}{5}=3.0
$$

The implication is that any items with mean value of 3.0 is accepted as "agree" while any item with mean value less than 3.0 is "disagree".

Research question one -To what extent does knowledge of family planning influences usage of family planning methods among married couples in Abakpa Nike?

Table 7. Positive knowledge of family planning methods among married couples in abakpa

\begin{tabular}{|l|l|l|l|}
\hline Response & F & $\mathbf{X}$ & $\mathbf{F x}$ \\
\hline Strongly Agree & 180 & 5 & 900 \\
\hline Agree & 90 & 4 & 360 \\
\hline Undecided & 15 & 3 & 45 \\
\hline Strongly Disagree & 3 & 2 & 6 \\
\hline Disagree & 2 & 1 & 2 \\
\hline Total & 290 & 15 & $\begin{array}{l}1313 \\
\overline{\mathbf{X}}=\frac{\mathbf{1 3 1 3}}{\mathbf{2 9 0}}=\mathbf{4 . 5}\end{array}$ \\
\hline
\end{tabular}

Source: Author's computations

From the above table, it can be seen that 4.5 is greater than mean value of the likert,3.0.Therefore, it can be concluded that there is positive knowledge of family planning methods among married couples in Abakpa.

Research question two -What are the attitudes of the married couples towards family planning methods in Abakpa Nike?

From the responses above, the married couples described their attitudes towards family planning methods as to constitute, husbands involvement in family decision, support of national policy of 4 children per family and that Contraceptives actually effective in planning families in Abakpa Nke, Enugu with mean score value of 4.6,4.4 and 4.2 respectively. On the other hand, the outcome of the above analysis indicates the following do not portray the attitudes of the married couples towards family planning methods in the area under study, i.e, It is against culture and religion, Only females should use contraceptives, Contraceptives are ineffective, It encourages promiscuity, Diminishes sexual pleasure, It is only for the literate, family planning make its users promiscuous, Contraceptives harmful because of their side effects and Family planning services somewhat expensive with mean score value of 1.8, 1.7, 1.6, 2.7, 2.5, 1.5, 1.8, 2.4 and 1.5 respectively. By this analysis, it can be concluded that husband's involvement in family decision, support of national policy of 4 children per family and Contraceptives actually being effective in planning families control the attitude of married couple towards the use family planning methods in Abakpa Nke, Enugu.

Research question three- How is the extent of practice of family planning methods among married couples in Abakpa Nike?

Table 8. Distribution of respondents, on whether there is adequate practice of family planning methods among married couples in Abakpa

\begin{tabular}{|l|l|l|l|}
\hline Response & F & X & Fx \\
\hline Strongly Agree & 120 & 5 & 600 \\
\hline Agree & 140 & 4 & 560 \\
\hline Undecided & 15 & 3 & 45 \\
\hline Strongly Disagree & 3 & 2 & 6 \\
\hline Disagree & 2 & 1 & 2 \\
\hline Total & 290 & 15 & $\begin{array}{l}1213 \\
\overline{\mathbf{X}}=\frac{1213}{290}=4.2\end{array}$ \\
\hline
\end{tabular}

Source: Author's computations 
From the above table, it can be seen that 4.2 is greater than mean value of the likert,3.0.Therefore, it can be concluded that there is adequate practice of family planning methods among married couples in Abakpa.

Research question four-What are the factors that influence family planning practice among married couples in Abakpa Nike?

\section{Summary of findings}

From the data presented and analyzed above, the following deduction could be made:

1. There is positive knowledge of family planning methods among married couples in Abakpa.

2. Husbands involvement in family decision, support of national policy of 4 children per family and Contraceptives actually being effective in planning families control the attitude of married couple towards the use family planning methods in Abakpa Nke, Enugu.

3. There is adequate practice of family planning methods among married couples in Abakpa.

4. Effectiveness and Partner involvement were the major factors influencing the Choice of Family Planning in Abakpa Nike, Enugu,

\section{Discussion of findings}

From the study, it was obvious that there is positive knowledge of family planning methods among married couples in Abakpa. Generally high among the respondents with an average of 266 in 290 respondents knowing male condom and injectables were the most well-known methods in Abakpa Nike. This high level of awareness has been similarly reported by previous studies within and outside Nigeria. (Anyanwu, 2015; Rozi et al.; 2008; Lundgren et al.; 2005; Mkangi, 2001) The knowledge of respondents about contraception/family planning was also high with about 270 respondents having good knowledge of contraception. This was also corroborated by Gbalahan (2015) in their study carried out in south western Nigeria. This pattern should be expected in light of much enlightenment that is on-going on the issue of family planning in the country. It is however still worthy of note that some contraceptive methods were very unpopular among the respondents. Only about a quarter knew about the diaphragm and implants and not up to $1 \%$ of the respondents knew about female condoms as methods of contraception. This is most likely due to the fact these methods are not readily available and are relatively more expensive than the other commoner methods like the male condoms.

Most of the respondents were favourably disposed towards contraception with more than fourfifths having a positive attitude towards contraception. However about 88 in 290 respondents felt contraception encourages promiscuity. This may be due to the conservative nature of typical African societies and could be one of the complex sociological factors (Eko, 2013) affecting contraceptive usage in African communities. Furthermore, nearly $90 \%$ of the respondents felt the husbands should be involved in family planning decisions and this is important because man approval and decision making has been said to be very important in utilizing family planning services, (Donati, Shah et al, 2008;) and this further stresses the need to carry men along in family planning campaigns.

The prevalence of modern contraceptive methods usage among the respondents was $89 \%$ with Effectiveness and Partner involvement being the predominant reasons for choice of contraceptive methods. This prevalence is higher than the findings of other studies in rural areas in Nigeria (Lundgren et al.; 2005) and other developing countries.

\section{Conclusion}

Knowledge of modern contraceptives is high in a study population. Substantial proportion of married couples had positive attitude towards modern contraceptives and hence more room for increasing more contraceptive use in a study population, though negative attitude of husbands towards modern contraceptive and lack of spousal communication on family planning could be a limitation. Regarding modern contraceptive prevalence rate, although there was some improvement compared to the past national averages, however, the current figure for prevalence rate is still low when compared to the national target. Likelihood (chances) of being current user of modern contraceptives by a woman increased with increase in education level, having higher number of living children, spousal communication on modern contraceptives, (i.e., Frequently talking/discussing family 
planning/modern contraceptives among married couples), woman participation in decisions making regarding fertility in a family, husband approval of modern contraceptives and having positive attitudes towards modern contraceptives (i.e., tinking that benefits of modern contraceptives outweighs negative effects). If had ever encountered side effects and living far from health facility by a woman were associated with reduction in odds (chances) of being current user of modern contraceptives.

\section{Recommendations}

The following recommendations were made based on the findings:

It is therefore necessary for religious leaders to be targeted and carried along in the campaign for modern contraceptive methods.

The mass media should also be encouraged to do more in public (eg traditional method) have been associated with high enlightenment on the benefits of modern contraceptive methods. Awareness and pattern of utilizing family planning services among married couples in Abakpa Nike, Enugu.

Furthermore, campaigns to empower women such as emphasis on their education, encouraging gender balance by changing community attitude towards position/status of women in a household and in a society as a whole should be strengthened. This would improve their participation in household decisions including those related to fertility and contraceptive use.

More education/counseling services to women on how to handle/deal with side effects associated with various modern contraceptives methods should be given due weight and campaigns against myths and misbeliefs that negatively affect use of modern contraceptive in the study population should be initiated

\section{Suggestion for further study}

Given the imperative of family planning knowledge, attitude and practices in our nation Nigeria, the researcher therefore suggests that "family planning knowledge, attitude and practices in rural area" should be considered for further studies.

\section{Acknowledgment}

My thanks goes to Amoge Udeani for your physical support to the success of this work. I also want to thank my Chief Mr Ngene C.I for his financial support. May God bless you all.

\section{References}

[1]. Akin, A. (2007). "Emergence of Family Planning Programme in Turkey," in Robinson W.C. and J.A. Ross (eds.) the Global Family Planning Revolution: Three Decades of Population Policies and Programmes. Washington: Green Press Initiative: 85-102.

[2]. Anyanwu, J. I., Ezegbe, B.N., \& Eskay, M. (2015). Family planning in Nigeria: a myth or reality? Implications for education: Journal of Education and Practice, 4, (15):108-113Bell, S. (1992). "Birth Control," in the Boston Women's Health Book Collective: The New Our Bodies, Ourselves. New York: Touchstone.

[3]. Diaz, M. et al (1999). Informed choice in international family planning service delivery: strategies for the 21st century, New York: AVSC International:22

[4]. Dixon-Mueller, R. (1993) "The Sexuality Connection in Reproductive Health," in Studies in Family Planning, 24(5):269-282.

[5]. Donati S, Hamam R, Medda E. (2000). Family planning KAP survey in Gaza. SocSci Med; 50:841-849.

[6]. Ekhareafo, D.O. \& Moyaki, M.G (2015). Knowledge, Attitude and Practice of Family Planning Among Air Men in the Sam Ethnan Air Force Base, Ikeja, Lagos: An International Multidisciplinary Journal, Ethiopia, 9(1):183-198.

[7]. Eko, J. E, Kalu, O. O.\& Offiong, D.A (2013). Prevalence of contraceptive use among women of reproductive age in Calabar metropolis, southern Nigeria: International Journal of Humanities and Social Science Invention. 2(6):27-34.

[8]. Gbolahan, A., Oni \& James, M. (2015). Family Planning Knowledge, Attitudes and Practices of Males in llorin, Nigeria: International Family Planning Perspectives, 17(2):50-54. 
DOI: $10.21522 /$ TIJPH.2013.06.02.Art022

ISSN: $2520-3134$

[9]. Lasisi, C. J., Bassey, T. I., Ita, A. E., \& Awoyemi, O. K. (2014). Awareness and Utilization of Family Planning among Married Women in the Traditional Core Areas of Ibadan, Oyo State: Nova Journal of Humanities and Social Sciences, 3(2): 1-8.

[10]. Mkangi K (2001). The Social Cost of Smaller Nuclear Families: A Critique of demographic transition. Dev. Stud., (2): 43 - 49.

[11]. National Population Commission (NPC) [Nigeria] \& ICF Macro (2009). NigeriaDemographic and Health Survey 2008. Abuja, Nigeria: National Population Commission and ICF Macro. AFRREV, 9 (1).

[12]. Nwokocha, E. E. (2006). Pregnancy Outcomes among the Ibani of Rivers State, Nigeria: Findings from Case-studies. African Population Studies, 21(1).

[13]. Olaitan, O.L (2011). Factors influencing the choice of family planning among couples in southwest Nigeria: International Journal of Medicine and Medical Sciences, 3(7): 227-232.

[14]. Olakojo, O. A. (2012). Knowledge, attitudes and practices of married women in Nigeria towards family planning: Journal of Sociology, Psychology and Anthropology in Practice, (3):18-25.

[15]. Olawepo, R. A. \& Okedare, E.A. (2006). Men's Attitudes towards Family Planning in a Traditional Urban Centre: An Example from Ilorin, Nigeria. Journal of Social Sciences. 13 (2): 83-90.

[16]. Olugbenga-Bello, A., Abodunrin, O., \& Adeomi, A.A. (2011).Contraceptive Practices among women in a rural communities in South-Western Nigeria. Global Journal of Medical Research: 11(2):12-19.

[17]. Oyefara, J.L. (2011). Socio-Cultural Context of Adolescent Fertility in Yoruba Society: Insight from Osun State, Nigeria. Lagos: Concept Publications.

[18]. Oyefara, J.L. (2012). Women age at first birth and knowledge of family planning methods in Yoruba society, Nigeria: Journal of Sociological Research, 3(2):249-271.

[19]. Ozumba, C. O. I. (2011). Family planning among married men: a pilot study in Abakpa Nike Enugu State Nigeria. Retrieved from: http://uaps2011.princeton.edu/papers/110374.

[20]. Rozina, M. Uzma, A and Haleema, A. H (2008). Contraceptive knowledge, attitude and practice among rural women: Journal of the College of Physicians and Surgeons Pakistan, 18 (9): 542-545.

[21]. Sanhueza, H. (2007). "Family Planning in Chile: A Tale of the Unexpected," In Robinsin, W.C. \& J.A. Ross (eds.). The Global Family Planning Revolution: Three Decades of Population Policies and Programmes. Washington: Green Press Initiative: 105-129.

[22]. Sezer, K. Simge, Z \& Leyla, D (2013). Influence of age on the usage of family planning methods by turkish married men living in south eastern turkey: Turkish Journal of Medical Sciences, 43: 756-763.

[23]. Timothy, C. O., Nelson, W. W \& Tom, K. M (2011). Contraceptive Use among Women of Reproductive Age in Kenya's City Slums: International Journal of Business and Social Science, 2(1):22-43.

[24]. USAID. (2007). "Contraceptive Trends in Developing Countries: DHS Comparative Report 16." Maryland: Macro International Inc., World population projection. 